\title{
The contribution of geophysics to archaeology: a case study of an ancient canal of the Oc Eo culture in the Mekong Delta, Vietnam
}

\author{
Le Ngoc Thanh ${ }^{1}$, Nguyen Quang Dung ${ }^{1}$, Nguyen Quang Bac ${ }^{2}$, \\ Nguyen Quang Mien ${ }^{3}$, Nguyen Dan $\mathrm{Vu}^{4}$, Duong Ba Man ${ }^{1}$, Nguyen Dinh Chau ${ }^{5}$ \\ ${ }^{1}$ Ho Chi Minh City Institute of Resources Geography, VAST; Vietnam; e-mail: Inthanh@hcmig.vast.vn (corresponding author) \\ ${ }^{2}$ Institute of Technology, VINASA; Vietnam \\ ${ }^{3}$ Institute of Archaeology, VASS; Vietnam \\ ${ }^{4}$ South Vietnam Geological Mapping Division; Vietnam \\ ${ }^{5}$ AGH University of Science and Technology; Krakow, Poland
}

(C) 2019 Authors. This is an open access publication, which can be used, distributed and reproduced in any medium according to the Creative Commons CC-BY 4.0 License requiring that the original work has been properly cited.

Received: 07 January 2019; accepted: 19 February 2019; first published online: 14 March 2019

\begin{abstract}
Generally, underground ancient canals are infilled with alluvial materials, with the canal bed and substrate often having different resistivity values. This study aimed to determine the location and morphology of Malleret's ancient canal 16 located to the southeast of the Ba The mountain, Mekong Delta, Vietnam by means of geophysical techniques. Two geophysical methods were used: electromagnetic profile and electric resisitivity tomography. A geoelectric structure $70 \mathrm{~m}$ long with $70-95 \mathrm{mS} / \mathrm{m}$ of apparent conductivity was found. On the electrical resistivity tomography section, a resistivity zone of 10-20 $\Omega \cdot \mathrm{m}, 1-4 \mathrm{~m}$ deep, $70 \mathrm{~m}$ wide corresponds to the mentioned above geoelectric structure, which is in an asymmetric U-shape extending toward the southeastern bank of canal 16. Hand-augering confirmed that the canal bed is fully incised into Holocene sediments as a substrate which stretches down to the Pleistocene. The sediments are composed of loams mixed with plant remains with a resistivity $\rho \sim 10-15 \Omega \cdot \mathrm{m}$. Both of the canal banks at a depth of $5 \mathrm{~m}$ are made up of Holocene sediments ( $\rho \sim 4-10 \Omega \cdot \mathrm{m})$. The ${ }^{14} \mathrm{C}$ measurements determined the age of the organic matter in the canal as being equal to $1210 \pm 85 \mathrm{BP}$, suggesting canal 16 ceased being operational at that time. The precise positioning of canal 16 on the ground surface, as well as identifying the morphology of the canal bed, were corroborated by geophysical techniques. The obtained results are of considerable value to archaeologists.
\end{abstract}

Keywords: electromagnetic profiling, electrical resistivity tomography, hand-auger, radiocarbon dating, ancient canal, alluvial deposit, Oc Eo culture, Ba The mountain

\section{INTRODUCTION}

Geophysical instruments and their related software have developed strongly with the support of information technology over the past two decades (Gourry et al. 2003, Loke et al. 2013, Giang et al. 2013-2014, Cygal et al. 2016, Gołębiowski et al. 2017, Osinowo \& Falufosi 2018). Hence geophysical techniques have been effectively used in archaeology, especially with the electrical, magnetic, electromagnetic and ground penetrating radar methods available, to detect the buried relics of ancient constructions (Vogelsang 1995, Basheer et al. 2014, Selim et al. 2014, Abueladas et al. 2017).

The archaeological relics of the Oc Eo culture are mainly situated in the An Giang and Kien Giang provinces in Mekong Delta. Ancient canals connected the towns together in the region to form a remarkable network of waterways. Based on French's aerial photographs of the Mekong 
Delta, Paris $(1931,1941)$ identified and numbered five ancient canals radiating southwards from Angkor Borei (Cambodia). Canals 1, 2 and 3 were short canals within the Angkor Borei area, canal 4 toward $\mathrm{Ba}$ The area and canal 5 toward Chau Doc, Vietnam (Fig. 1). Using Paris's maps of the ancient canals, aerial photographs taken during the period between 1928-1953, as well as airborne observation and field investigation, Malleret $(1959,1963)$ mapped three ancient canals at scales 1:400,000 and 1:100,000 with an additional total of $23 \mathrm{ca}$ nals numbered continuously with Paris's numbers from 6 to 28, and tens of trenches suspected of being ancient canals. Additionally, he also mapped the ancient city of Oc Eo at scale 1:10,000 with a segment of canal 16 flowing across the city and dividing it into two parts (Fig. 1). Nowadays, the ancient canals have been leveled flat due to anthropogenic activity, especially the cultivation of rice, causing them to disappear completely on the ground. Therefore, it is necessary to identify the precise location and dimensions of the ancient canals since they have high cultural heritage values not only for Vietnam but also for the world.

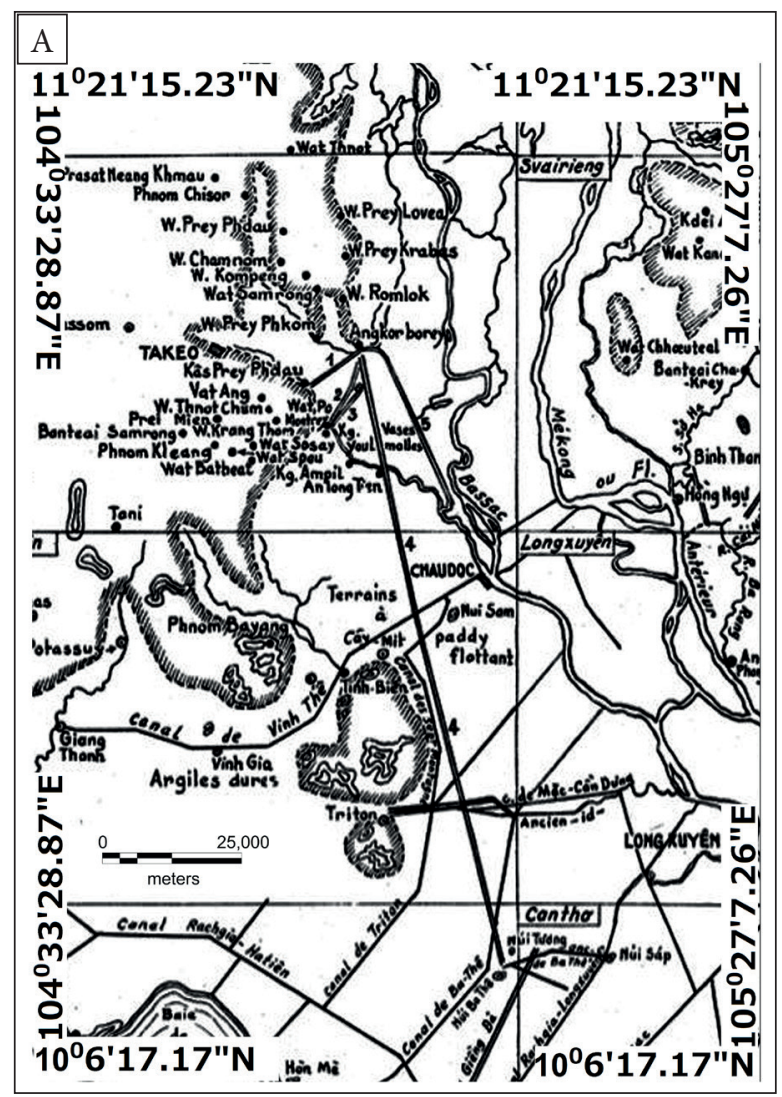

Research of Malleret's ancient canal 16 plays an important role in understanding of Oc Eo culture (Figs. 1, 2). According to Bourdonneau (2003), canal 16 ran across the Oc Eo site of about $50 \mathrm{~m}$ wide. At its origin, the canal deviated slightly to the west to connect with one of the branches of the Long Xuyen River. At its southwestern end, the canal flowed into the ancient Takeo River. Near Ba The mountain, canal 16 was dug into a wet clay layer to the bed of $264 \mathrm{~cm}$ deep from the present ground surface at coordinates (UTM): $x=0519375 ; y=1133559$, but over time gradually filled with sediments and ceased operation about 14 centuries ago (Thuyen 2005). Recently, with an interdisciplinary approach consisting of remote sensing, GIS and mathematical modeling, we found that canal 16 is about $40 \mathrm{~km}$ long in NE-SW direction from Trung Phu 2 hamlet, Vinh Phu commune, Thoai Son district, An Giang province $\left(10^{\circ} 20^{\prime} 56.27^{\prime \prime} \mathrm{N} ; 105^{\circ} 14^{\prime} 45.86^{\prime \prime} \mathrm{E}\right)$ across the ancient city of Oc Eo toward Takeo hamlet, Tan Hoi commune, Tan Hiep district, Kien Giang province $\left(10^{\circ} 02^{\prime} 21.56^{\prime \prime} \mathrm{N} ; 105^{\circ} 04^{\prime} 37.84^{\prime \prime} \mathrm{E}\right)$ (Bac et al. 2018).

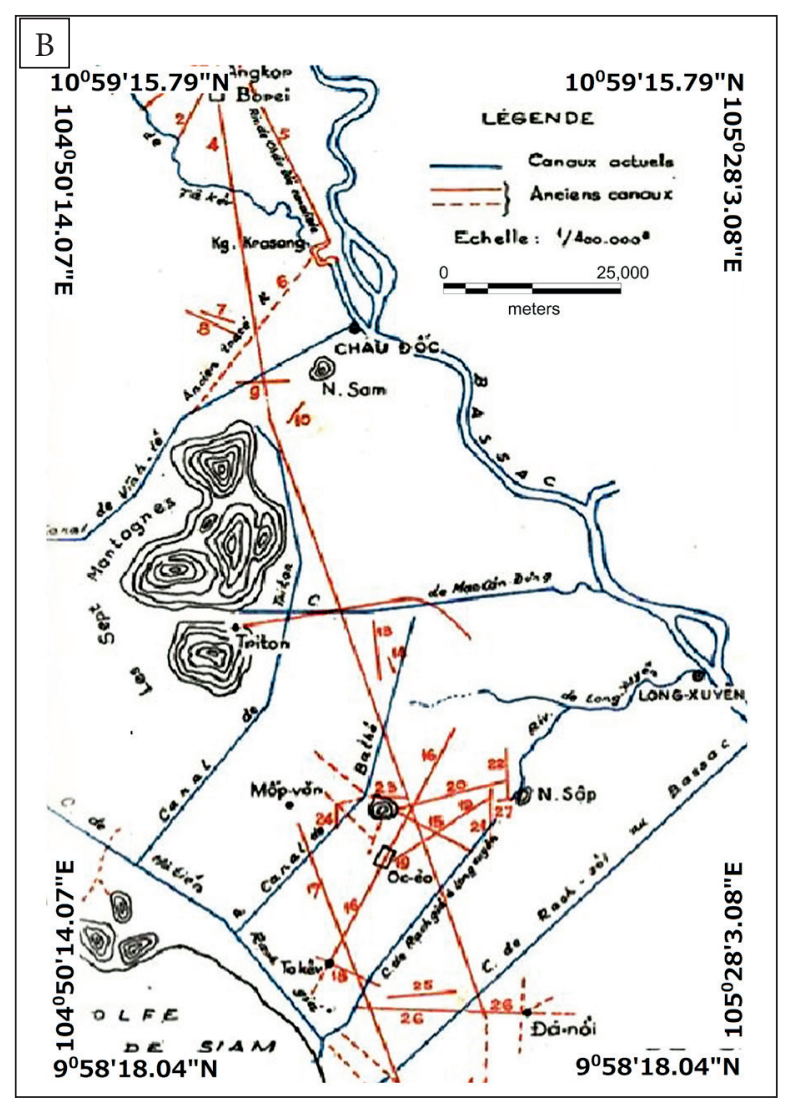

Fig. 1. Map of the network of ancient canals by Pierre Paris (1941) (A) and Louis Malleret (1959) (B) in Lower Mekong Delta 


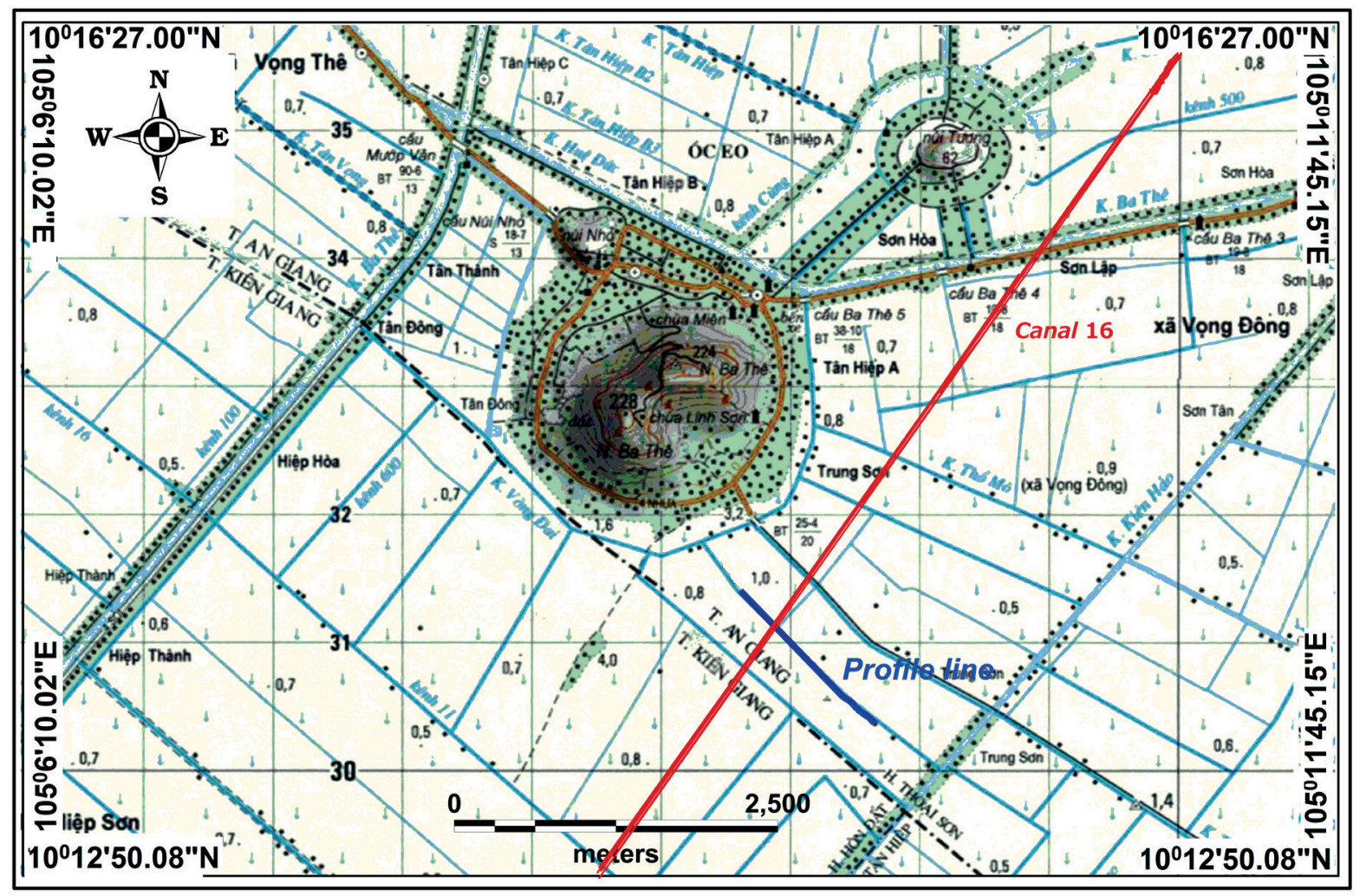

Fig. 2. Location of survey area

By both hand-augering and trenching showed that the maximum depth of canal 2 prior to infilling was between $1.20 \mathrm{~m}$ and $1.65 \mathrm{~m}$ (Bishop et al. 2003). The width of the canal was at least $15.75 \mathrm{~m}$ presumably up to $25 \mathrm{~m}$.

Canal 2 was indicated by the shallow U-shaped geometry of its boundary which cut into the substrate and represented the base of the canal, but the findings of Paris's canal 1 on the ground surface were not achieved. Geophysical techniques are considered as another possibility in the such archeological studies. The aims of this study were to use electromagnetic profiling (EMP) and electrical resistivity tomography (ERT) to reveal canal 16 on the ground surface, traces of which were mapped in previous studies; to identify the morphology of canal bed in order to provide the targets for boreholes.

\section{SURVEY AREA}

\section{Location}

The Mekong Delta is a wide, low-lying delta which is $49,500 \mathrm{~km}^{2}$ in area. The delta plain is the third largest in the world, 50\% greater than the Yangtze Delta, and is only exceeded by the Amazon and Ganges-Brahmaputra deltas. A sea-level curve for the Mekong Delta, which was developed for the last 15,000 calyr, indicated a rapid sea-level rise since the last glacial episode. After reaching its maximum height around 5500 calyr BP, the sea level has been lowering slightly until recently (Zuo et al. 2010, Linh et al. 2015). The survey area belongs to Mekong Delta and located to the southeast of Ba The mountain at Thoai Son district, An Giang province (Fig. 2).

\section{Geology}

Generally, the study area is composed of Devonian to Holocene formations. Pre-Holocene formations are revealed only at mountain massifs and hill remains. Holocene sediments are widely exposed on the ground surface, which almost covers Neogene to Late Pleistocene sediments to a thickness of 0.5-76.0 m (Linh et al. 2015).

Pre-Holocene geological units are formations of Early Devon-Carbon to Late Pleistocene age 
and undifferentiated Quaternary sediments (dQ) as well as intrusive magmatic rocks aged Late Triassic to Paleocene. Upper Pleistocene sediments $\left(\mathrm{Q}_{1}{ }^{3}\right)$ of marine genesis $\left(\mathrm{mQ}_{1}{ }^{3}\right)$ are distributed sparsely in the Tinh Bien and Tri Ton districts, the lithological composition of which includes silty sand, clayey sand, yellowish gray clayey silt, 2-3 m thick. Undifferentiated Quaternary sediments are deluvium - the product washed away from mountain slopes which was deposited around the mountain ranges in Tinh Bien-Tri Ton with width up to $200 \mathrm{~m}$, comprising chips, pebbles, gravel, sand, silt, 0.5-2.0 m thick. Intrusive magmatic formations are distributed around the mountain massifs and hill remains.

Holocene sediments are commonly revealed on the present ground surface with two main units: (i) Lower part, middle Holocene sediment $\left(\mathrm{Q}_{2}{ }_{1}^{2}\right)$ is in the form of a marine shelf, at the height 2-4 m in Tinh Bien-Tri Ton, encountered in a borehole up to $35 \mathrm{~m}$ deep, 1-33 m thick, which is Holocene marine transgression sediment $(\mathrm{m})$ including clay, silty clay, fine sand mixed with silty sand of abundant shell relics; (ii) High part, middle Holocene sediment $\left(\mathrm{Q}_{2}{ }_{2}^{2}\right)$ is exposed in the survey area, encountered in a borehole up to $36 \mathrm{~m}$ deep, which is Holocene marine regression sediment of a different genesis, $0.8-25.0 \mathrm{~m}$ thick.

Alluvial-marsh (ab) sediment is distributed across Tinh Bien, 0.1-10.0 km wide, about $10 \mathrm{~km}$ long, including clay, silt, plant remains and peat, whereas alluvial-marine $(\mathrm{am})$ sediment is located along the banks of Mekong River and Bassac River, which spreads to Tinh Bien-Tri Ton consisting of clay, silty clay mixed with sand and plant remains, locally with yellowish gray, yellow mottles. The survey line is situated within the alluvial-marsh sediment $\left(\mathrm{abQ}_{2}{ }^{23}{ }_{2}\right)$ (Fig. 3).

\section{Resistivity of Quaternary sediments}

Electrical methods, such as electrical vertical sounding, electric profiling, stimulated polarization and electrical resistivity tomography, have been conducted to study geology, hydrogeology, engineering geology, geohazards and environmental pollution in Mekong Delta since 1975. A synthesis of the results demonstrates the resistivity values of Quaternary sediments in the Table 1 (Giang et al. 2009, Giang et al. 2012, Thanh et al. 2013).

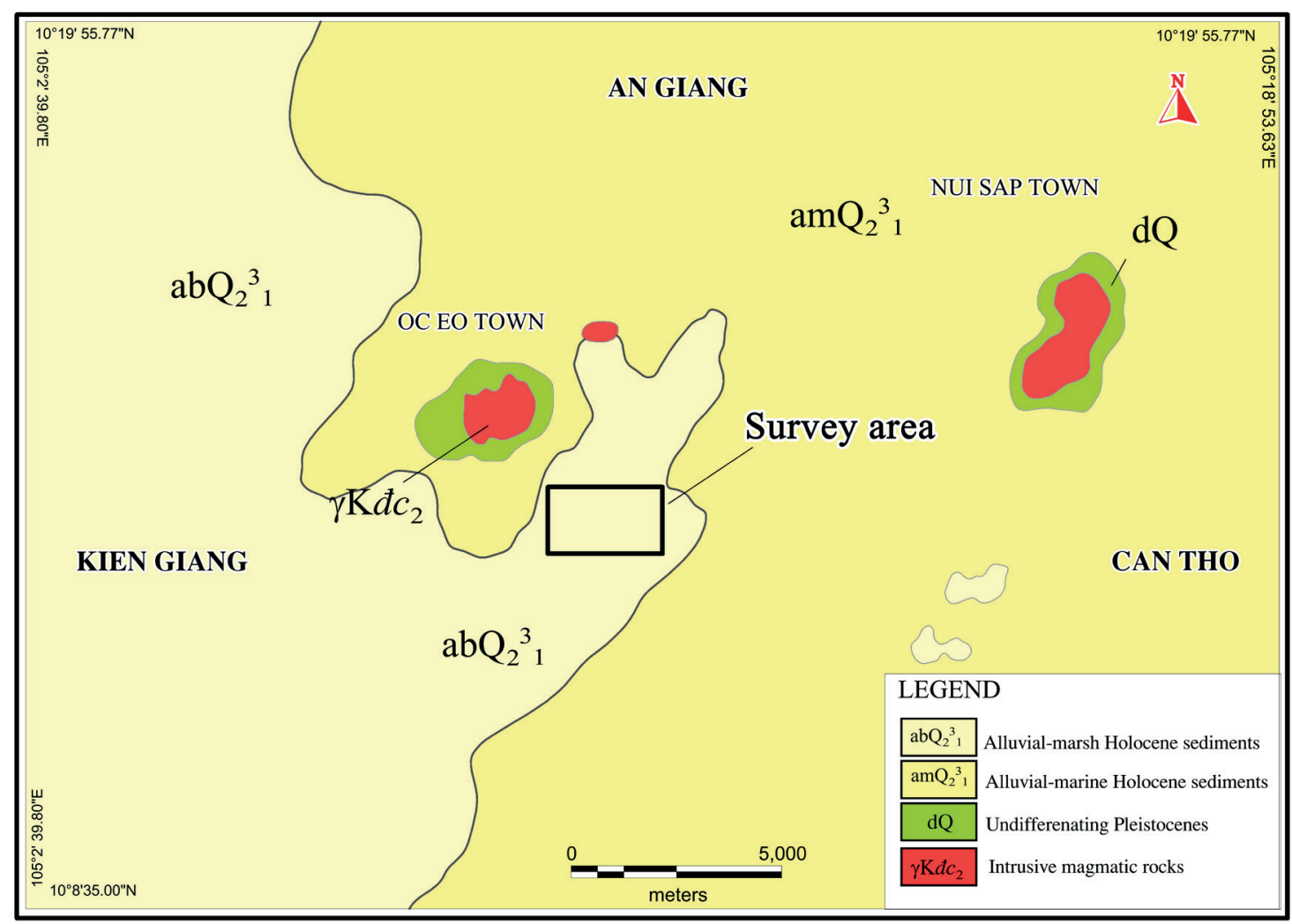

Fig. 3. Geological map of survey area 
Table 1

Resistivity of Quaternary sediments in Mekong Delta

\begin{tabular}{|c|c|c|c|}
\hline \multirow{3}{*}{ Materials } & \multicolumn{3}{|c|}{ Resistivity $[\Omega \cdot \mathbf{m}]$} \\
\hline & \multirow{2}{*}{$\begin{array}{c}\text { Telford } \\
\text { et al. (1990) }\end{array}$} & \multicolumn{2}{|c|}{ sediments of Mekong Delta } \\
\hline & & Holocene & Pleistocene \\
\hline $\begin{array}{l}\text { Alluvium } \\
\text { and sands }\end{array}$ & $10-800$ & $10-20$ & - \\
\hline Clays & $1-100$ & $1-10$ & - \\
\hline Clayish silts & - & $0.5-20.0$ & $5-15$ \\
\hline Sandy silts & - & $0.5-5.0$ & $1-50$ \\
\hline
\end{tabular}

Although the alluvium, sands and clays have the same initial values, but the ranges of the resistivity measured by the authors for the mentioned sediments in Mekong Delta are 10-40\% smaller compared to the data published by Telford et al. (1990).

It should be note that the conductivity of the substrate is sometimes similar to that of alluvial infill, which can make it difficult to discriminate between two formations. However, the above data show that contrasts in electrical resistivity between alluvial infill and Holocene sediments could be sufficient to use electromagnetic profiling and resistivity topography to detect geoelectric structures at the small scale.

\section{METHODOLOGY}

Field work was carried out with digital and paper-printing maps, handheld GPS and interviews with local people in April 2018. Consequently, we determined upon a survey line $160 \mathrm{~m}$ long in a NE-SW direction across canal 16 (Fig. 2), the center of which is proposed to be located at coordinates $\left(10^{\circ} 13^{\prime} 36.61^{\prime \prime} \mathrm{N} ; 105^{\circ} 9^{\prime} 39.23^{\prime \prime} \mathrm{E}\right)$. The geophysical measurements and hand-auger on the survey line were conducted in July 2018.

\section{Electromagnetic profiling - EMP}

First, the EMP survey was conducted with a EM31$-\mathrm{MK} 2^{\mathrm{TM}}$ instrument used to measure the apparent conductivity of the shallow subsurface along the survey line with the array in the "vertical dipole" mode. This instrumental configuration was chosen because it is very sensitive to lateral variations of apparent conductivity and has a depth penetration of about 4-6 m.

Apparent conductivity data were collected with the DAT31W program installed in the EM31-MK2 instrument, which allows for the transfer of data files to a personal computer, and the data can then be displayed, edited, printed and plotted. The data files can serve as input for Geosoft, Surfer and other contour softwares with the suitable format (Fig. 4).

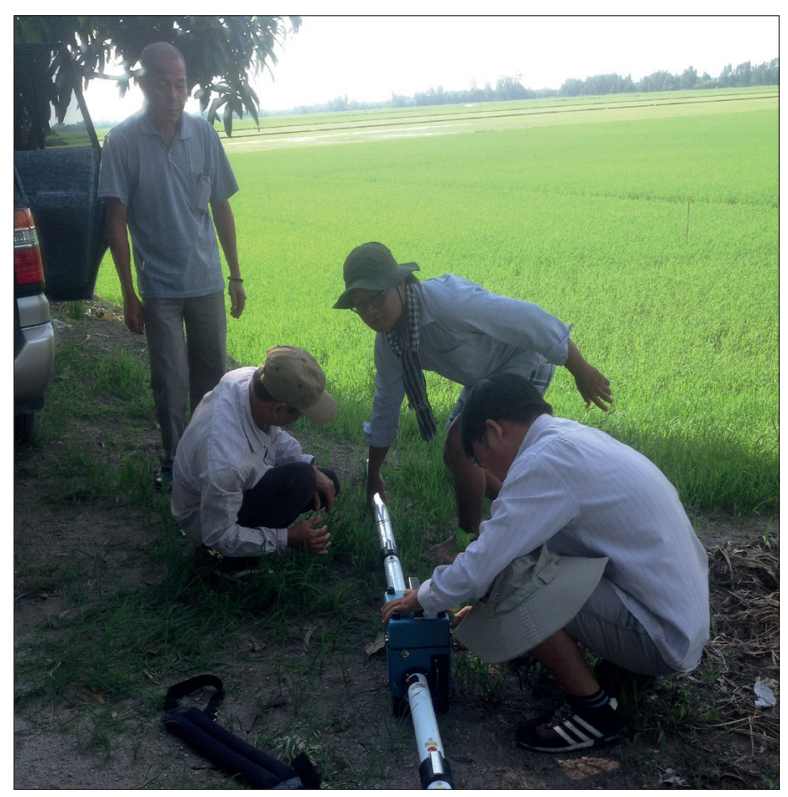

Fig. 4. Instrument EM31-MK2, manufactured by Geonics of Toronto, Canada

\section{Electrical resistivity tomography - ERT}

Two-dimension (2D) ERT is a geophysical method which was used widely in the survey at high resolutions. It is a combination of traditional vertical electrical sounding and profiling methods and thereby studies both vertical and horizontal changes in the resistivity of the subsurface in a two-dimensional form. Measurement data are expressed by an apparent resistivity pseudo-section: horizontal axis is the distance of electrodes on the survey line; the vertical axis is considered as the depth of penetration.

The ERT profile of $100 \mathrm{~m}$ long was designed based on the results of the EMP survey, namely starting at the $50^{\text {th }}$ meter of the survey line. Data acquisition was performed by means of a Lund multi-electrode switching system connected to an SAS4000 resistivity meter by ABEM $^{\mathrm{TM}}$ (Fig. 5). The system consisted of 40 electrodes with a spacing of $2.5 \mathrm{~m}$ and was able to measure the apparent resistivity of the subsurface automatically with a Wenner configuration. 


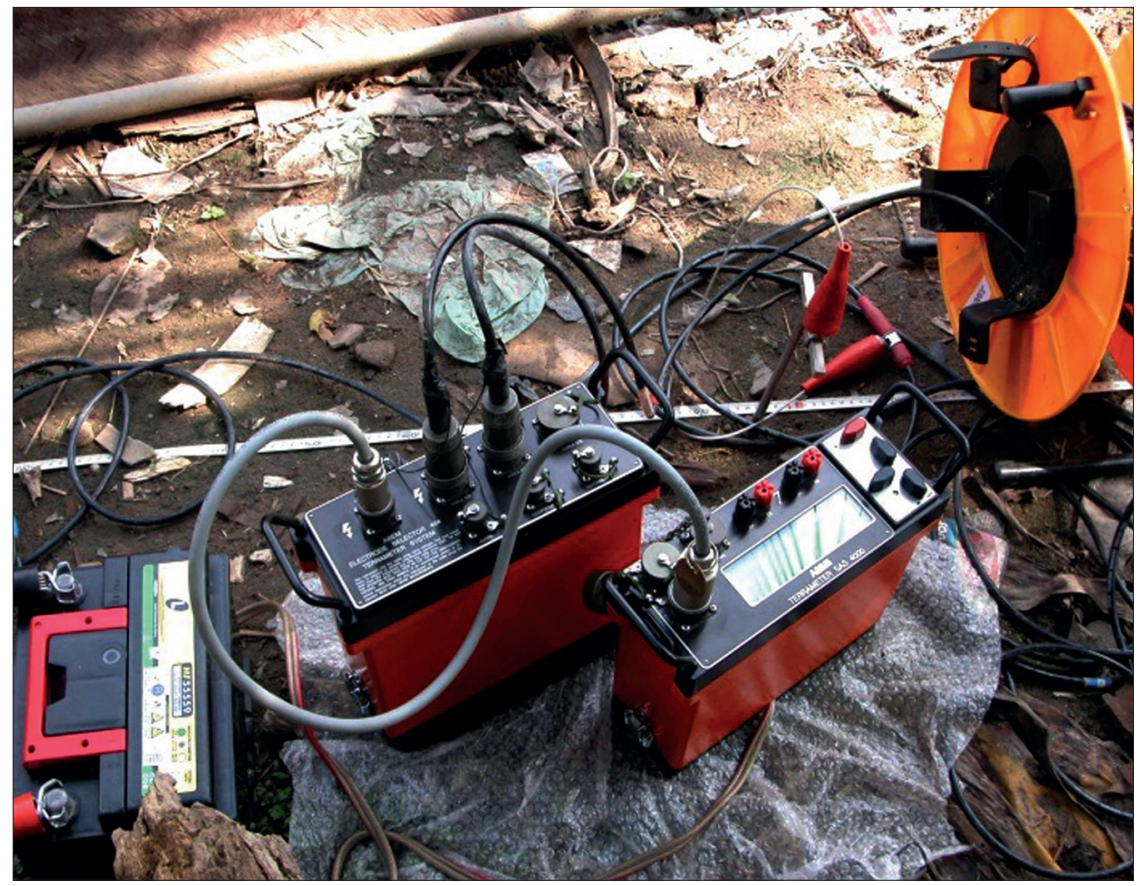

Fig. 5. Lund multi-electrode switching system connected to an SAS4000 resistivity meter of ABEM, Sweden

The RES2DINV computer program was used and automatically determined a $2 \mathrm{D}$ resistivity model for the subsurface for the data obtained from ERT surveys. This software is based on the smoothness-constrained least-squares method and a $2 \mathrm{D}$ subsurface model was obtained by the inversion of the apparent pseudo-section. The technique of inversion is automatic and does not require a prior model.



Fig. 6. Hand-augering on survey line

\section{Hand-augering}

Twelve boreholes with depths of up to $5.5 \mathrm{~m}$ at distances of between 5-20 m were hand-augered along the survey line across the traces of canal 16, currently a rice field. We described the stratigraphy and sampled all of the boreholes for sedimentary analysis and, in borehole LK10, for radiocarbon dating (Figs. 6, 7).



Fig. 7. Sampling for sedimentary analysis and radiocarbon dating 


\section{Radiocarbon dating}

The determination procedure of the specific activity of ${ }^{14} \mathrm{C}$ in the environmental material sample is written in detail by Neary (1999) and for the study materials in this work ${ }^{14} \mathrm{C}$ determination can be described briefly as follows:

Four soil core samples with at least $500 \mathrm{~g}$ of mass were taken at $1 \mathrm{~m}$ to $3.6 \mathrm{~m}$ of depth from the borehole LK10 $\left(10^{\circ} 13^{\prime} 36.80^{\prime \prime} \mathrm{N} ; 105^{\circ} 9^{\prime} 39.00^{\prime \prime} \mathrm{E}\right)$ and marked as S1, S2, S3 and S4. Since the obtained sedimentary core was almost the same, consisting of a black-grey fine clay and peat (Fig. 8), the distance between two neighboring samples was $\sim 0.6 \mathrm{~m}$.

The samples were placed in the plastic bags and sent to the Laboratory of the Vietnam National Archaeology Institute. At this laboratory, the samples were cleaned by mixing them with distilled water and filtered through a membrane filter with a $0.1 \mathrm{~mm}$ porosity, with inorganic materials being rejected. The mentioned work was repeated until only plant remained on the filter. The obtained samples were dried at $80^{\circ} \mathrm{C}$ over $24 \mathrm{~h}$, with the dry mass of the S1, S2, S3 and S4 samples being equal to $4.8 ; 3.3 ; 4.1$ and 4.6 g respectively. All the obtained samples were mixed and a part of the obtained material, which had an expected $4 \mathrm{~g}$ of carbon, was placed in a steel bomb. Oxygen was pumped into the bomb and all the organic material, together with the oxygen, was burned electrically. The $\mathrm{CO}_{2}$ gas was led by a special canal, cooled by liquid nitrogen and formed as dry ice. To separate the carbon from the $\mathrm{CO}_{2}$, the obtained sample was heated to $850^{\circ} \mathrm{C}$ with the lithium, in consequence the $\mathrm{Li}_{2} \mathrm{C}_{2}$ was formed. Subsequently, the carbon from $\mathrm{Li}_{2} \mathrm{C}_{2}$ was transformed into the form of acetylene $\left(\mathrm{C}_{2} \mathrm{H}_{2}\right)$ by means of a hydrolysis reaction. The acetylene was transformed into benzene $\left(\mathrm{C}_{6} \mathrm{H}_{6}\right)$ and the sample was weighed. Then, $2.5 \mathrm{~g}$ of the obtained benzene was placed into a glass vial, $7 \mathrm{ml}$ in volume, and the benzene was mixed with a liquid scintillator, HiSafe $3^{\mathrm{TM}}$ and the sample was measured using liquid scintillation counter Tricarb $2770 \mathrm{TR} / \mathrm{SL}^{\mathrm{TM}}$ with $70 \%$ of efficiency for $\beta$ particles emitted from the ${ }^{14} \mathrm{C}$. Using the mass of the obtained benzene and the net measured intensity (cpm), the specific activity of the obtained ${ }^{14} \mathrm{C}$ amounted to $11.66 \pm 0.12 \mathrm{dpm} / \mathrm{g}$ C. In reference to the specific activity of the standard NBS oxalic acid $(0.95 \times 13.56 \mathrm{dpm} / \mathrm{g} \mathrm{C})$ the calculated age of the study soil amounted to $1210 \pm 85$ year BP (the uncertainty including all of the uncertainties connected with the preparation and measurement of the carbon sample).

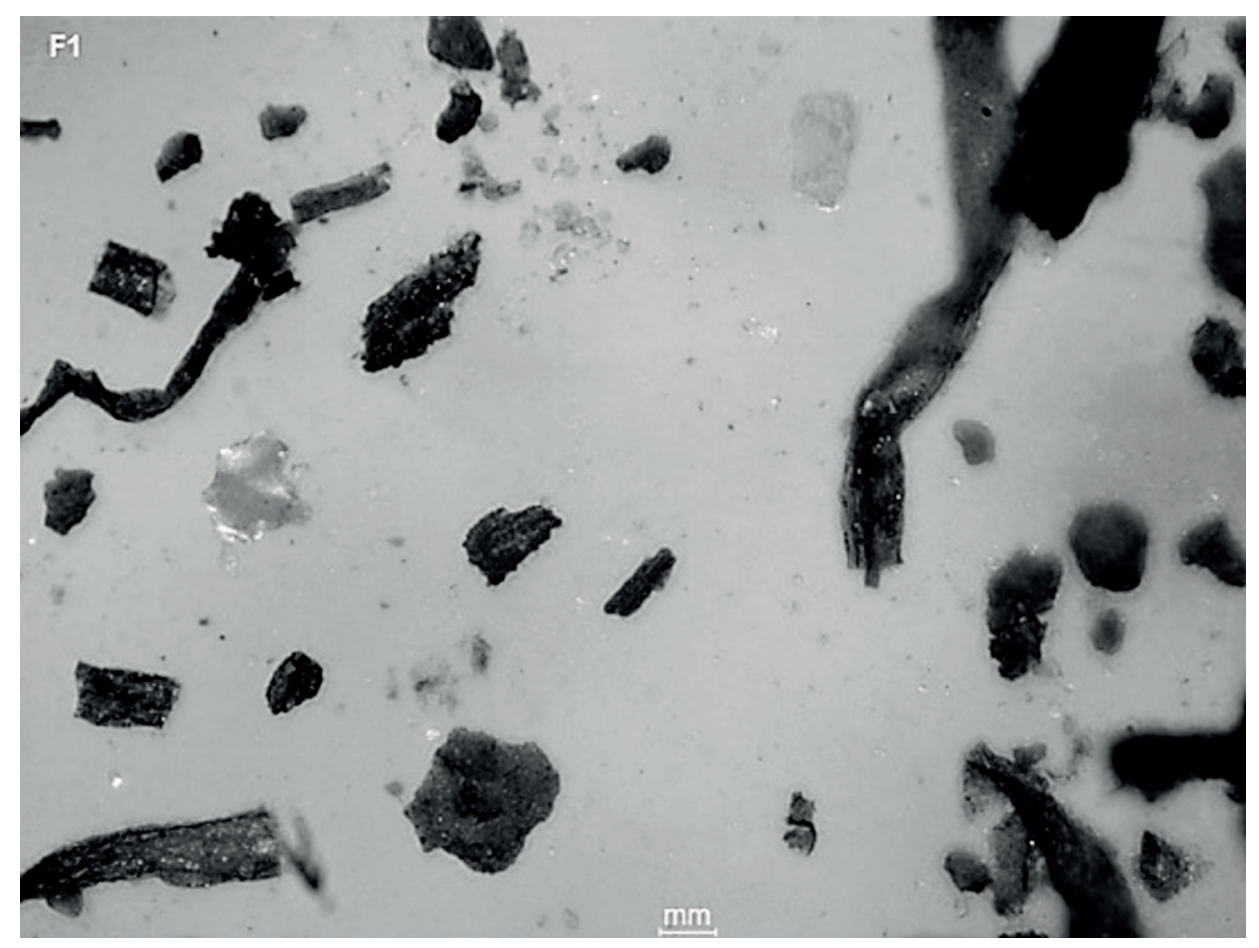

Fig. 8. Soil core sampler for radiocarbon dating 


\section{RESULTS}

The apparent conductivities measured on the profile by EMP is presented in Figure 9. The apparent conductivity ranges from 70 to $130 \mathrm{mS} / \mathrm{m}$. Based on the shape, the curve can be divided into four distinct sections: the first section, from the starting point to the $50^{\text {th }}$ meter, demonstrates small variations in apparent conductivity of around $95 \mathrm{mS} / \mathrm{m}$. The section can be regarded as a background value of the EMP profile; this is followed by a second section showing a geoelectric structure of $25 \mathrm{~m}$ long, in which there is a "positive anomaly" of apparent conductivity $(\sigma=95-130 \mathrm{mS} / \mathrm{m})$; next, there is the most interesting section - a third with a geoelectric structure $70 \mathrm{~m}$ long with a "negative anomaly" of conductivity $(\sigma=70-95 \mathrm{mS} / \mathrm{m})$. Within this section, the alluvial body of canal 16 is expected, and a last, short section indicates that the apparent conductivity is rising slightly, to about $110 \mathrm{mS} / \mathrm{m}$ (Fig. 9).



Fig. 9. EM31-MK2 survey line across the ancient canal 16

Indeed, on the ERT section it is possible to identify four main geoelectric zones: (i) a first zone about $1.0 \mathrm{~m}$ thick consisting of rice soils with a resistivity over $15 \Omega \cdot \mathrm{m}$; (ii) a second zone of lower resistivity of $10-20 \Omega \cdot \mathrm{m}, 1-4 \mathrm{~m}$ deep, $70 \mathrm{~m}$ wide from $25^{\text {th }}$ meter to the end, which is in an asymmetrical U-shape in accordance with a third section of the curve of apparent conductivity; (iii) underlying is a third zone of the lowest resistivity, less than $10 \Omega \cdot \mathrm{m}$, about $10 \mathrm{~m}$ thick, which rises up to the ground surface in both the northwestern and southeastern parts of the section; (iv) and the lowermost zone has a resistivity mostly similar to that of top soil (Fig. 10).

The geophysical interpretation provided the targets for boreholes. A geological section was built up in which the first borehole, LK8, was $22 \mathrm{~m}$ away from the first electrode of ERT profile in the southeast, indicated a burden of rice soils about $1 \mathrm{~m}$ thick ( $\rho \sim 15-35 \Omega \cdot \mathrm{m})$. Around the middle of the geological section, underlying is a canal bed that fully incises into the Holocene sediments down to a depth of $4 \mathrm{~m}$, made up of loams mixed with plant remains in a symmetrical U-shape from boreholes LK17, LK10 to LK16 $35 \mathrm{~m}$ long, and asymmetric from boreholes LK17, LK10, LK16, LK15, LK11 to LK12 $70 \mathrm{~m}$ long ( $\rho \sim 10-15 \Omega \cdot m)$. Both canal banks at a depth of up to $5 \mathrm{~m}$ are made up of Holocene sediments including softly to hard plastic clays, bluish grey loams and fine sands ( $\rho \sim 4-10 \Omega \cdot \mathrm{m}$ ). The lowermost subsurface is the Pleistocene sediments from a depth of $3.6 \mathrm{~m}$ including softly to hard plastic clayish silts in bluish grey color of intercalated reddish and yellowish brown ( $\rho \sim 4-35 \Omega \cdot m)$ (Fig. 11). 

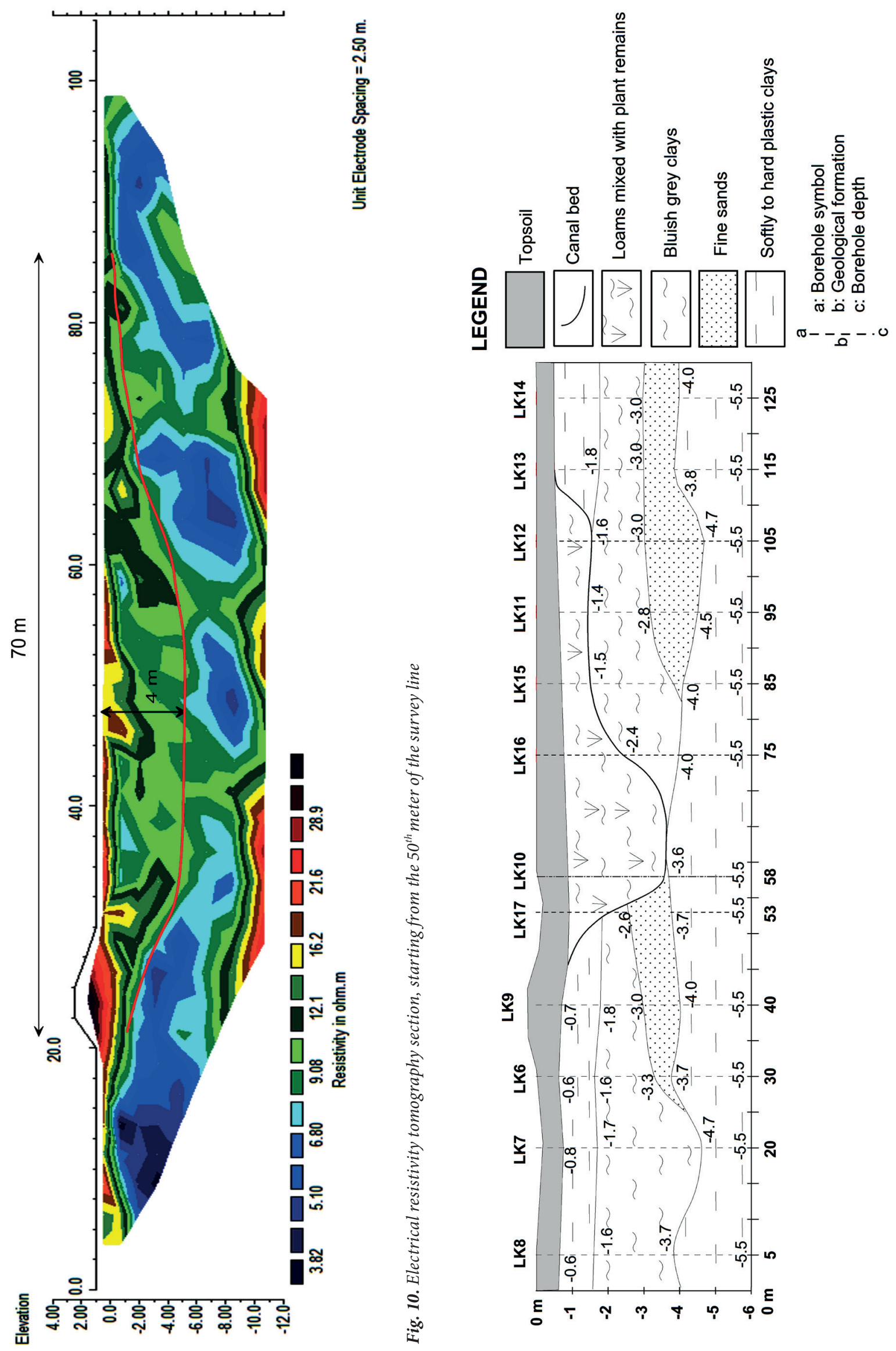

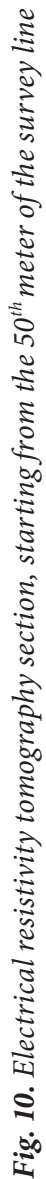

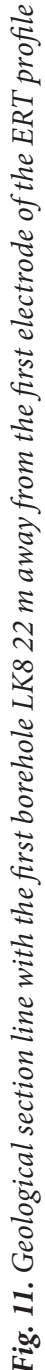




\section{DISCUSSION}

It is well known that the morphology and stratigraphy of ancient canal beds are the best determinants of its functioning. A canal bed is affected in turn by both anthropogenic and natural factors. The present study aimed to contribute an effectiveness of the geophysical techniques in such type of archeological investigation. We located Malleret's ancient canal 16 on the present ground surface and identified the morphology of the canal bed by two geophysical methods (EMP and ERT) with the support of hand-augering and radiocarbon dating.

Generally, our findings are consistent with the previous results, given the wide confidence interval among the studies. As we know, the width of a canal depends on the time taken and the resolution of remote sensing imagery. Therefore, the width of $50 \mathrm{~m}$ of canal 16 supplied by Bourdonneau (2003) could just be an average width of the entire canal. As a matter of fact, the present study indicated that the initial width of canal 16 was about $35 \mathrm{~m}$ and after that extended laterally $35 \mathrm{~m}$ to the southeast. Thuyen (2005) reported the depth of canal 16 as slightly smaller compared to that of this study. This can be explained by the fact that his borehole did not reach the bottom and the whole of the canal bed was not identified.

According to Bishop et al. (2003) the largest width and depth of canal 2 are much smaller (over $50 \%)$ compared to those of canal 16. It could be supposed that canal 2 has been incised into quite consolidated Pleistocene sediments consisting of mottled orange and gritty clay, which made it difficult to excavate at that time. Furthermore, canal 2 had mainly been used for transportation but less for agriculture. In contrast, canal 16 was completely incised into the Holocene sediments consisting mainly of soft clays, which facilitated deep excavation down to the Pleistocene surface. Canal 16 was therefore a broad, deep channel that made a direct connection between the ancient settlements of the Oc Eo area and the southwestern coastal zone, today northern Rach Gia city. This direct connection strongly implies that canal 16 functioned as a waterway for transport/communication and irrigation/drainage. Such a depth and width of the canal bed meant that it was presumably able to accommodate rather clumsy vessels.

It is also the soft clay materials that made both banks of canal 16 vulnerable to erosion and resulting in the southeastern asymmetry. It is presumably attributed to the influence of the hydrological regime over the course of many years. A northwestern strong overflow across canal 16 pouring water into the Mekong River and the southeastern Mekong Delta caused the erosion of the southeastern left bank of canal.

Canal 16 has undergone four phases: excavation, operation, infill and deposition. In survey area the flooding regime in many months of the year has contributed to quickly complete two last phases. After ceasing operation, the canal was gradually leveled flat and then deposited to build up the present topsoil. Radiocarbon analysis revealed that samples of organic matter in borehole LK10 aged much smaller compared with Holocene sediments (about 6000 years ago). It could be assumed that the canal bed was made flat about 1300 years ago, the average deposition rate in survey area is about $0.8 \mathrm{~mm}$ per year.

Our study confirms that an integrated research methodology, including remote sensing, GIS, mathematical modeling and finally geophysical techniques, particularly the two EMP and ERT methods, is a valuable contribution to archaeology. Compared to hand-augering and trenching, near-surface geophysical techniques that address hand-augering have been proven to be more effective in identifying the ancient canal bed, thereby positioning the appropriate sites of excavation for archaeological work. Additionally, the age of the plants occurring in the sedimentary material within canal 16 was determined by means of the ${ }^{14} \mathrm{C}$ method and amounted to $1210 \pm 85$ year BP (rf. section Radiocarbon dating). However, geophysical measurements are sometimes difficult to implement due to some unfavorable natural conditions during the rainy season in the Mekong Delta. It is therefore necessary to consider the possibility of a different combination of geophysical methods for archaeological purposes. 


\section{CONCLUSION}

Malleret's ancient canal 16 was positioned and the morphology of canal bed was identified by means of geophysics. The results were also confirmed by hand-augering and radiocarbon dating.

The width of canal 16 was $35 \mathrm{~m}$ and extended laterally $35 \mathrm{~m}$ to the southeast. The canal bed, prior to infilling and depositing, had incised fully into the Holocene sediments to a depth of $3 \mathrm{~m}$ and had encountered the Pleistocene surface. It was made up of loams mixed with plant remains in an asymmetric U-shape toward the southeastern bank, presumably due to erosion caused by the strong overflow from the northwestern Cambodia border. Canal 16 functioned as a waterway for transport/communication and irrigation/drainage and was able to accommodate rather clumsy vessels. It probably ceased operations about 13 centuries ago.

Positioning Malleret's ancient canals on the ground surface and studying the morphology and stratigraphy of canal beds is essential to evaluate their functioning in the past in order to understand and reconstruct the Oc Eo culture of Kingdom of Funan that once occupied the Mekong Delta, Vietnam.

We would like to express our thanks to the $\mathrm{Na}$ tional Space Science and Technology Program, 2016-2020 period (CNS/16-20) for the project "Application of remote sensing technology and GIS for Archaeological research in Southwestern Vietnam (focus on Oc Eo culture)". We thank Nguyen Huu Tuan and Vo Hong Son for their interpretation of the remote sensing imagery. The authors wish to express their sincere thanks to Prof. Dr. Jadwiga Jarzyna and the anonymous reviewers for their helpful suggestions and contributions to improve the quality of this article.

\section{REFERENCES}

Abueladas A.E., Akawwi E., Al-Ruzouq R. \& Alzoubi A., 2017. Using 2D and 3D CVES in archaeology at Umm Qais, Jordan. Journal of Applied Sciences, 17, 1, 41-47.

Bac N.Q., Thanh L.N., Son V.H. \& Tuan N.H., 2018. Determining the spatial distribution characteristics of some ancient canals in the Ba The area, Oc Eo, Nui Sap,
Dinh My and Da Noi (An Giang province). [in:] The History of Archaeology in the Asia-Pacific Region: The $21^{\text {st }}$ Congress of the Indo-Pacific Prehistory Association, 23-28 Sept., Hue, Vietnam.

Basheer A., Al-Imam A., Abdelmotaal A.M., Mostafa S.T. \& Elkhateeb S., 2014. Appliance of geophysical methods to detect the ancient remains at "Tell Defenneh" area, Ismailia, Egypt. Archaeological Discovery, 2, 71-82.

Bishop P., Sanderson D., \& Stark M.T., 2003. OSL and radiocarbon dating of a pre-Angkorian canal in the Mekong Delta, southern Cambodia. Journal of Archaeological Science, 31, 319-336.

Bourdonneau E., 2003. The ancient canal system of the Mekong Delta: Preliminary Report. [in:] Karlström A., Källén A. (eds.), Fishbones and Glittering Emblems: Southeast Asian Archaeology 2002, Museum of Far Eastern Antiquities, Stockholm, 257-270.

Cygal A., Stefaniuk M., Kret A. \& Kurowska M., 2016. The application of electrical resistivity tomography (ERT), induced polarization (IP) and electromagnetic conductivity (EMC) methods for the evaluation of technical condition of flood embankment corpus. Geology, Geophysics and Environment, 42 (3), 279-287.

Giang N.V., Thanh L.N. \& Dec J., 2009. Geophysical techniques for hydrogeological targets in semi-desert area in southern part of Vietnam. Geologia: kwartalnik Akademii Górniczo-Hutniczej im. Stanisława Staszica w Krakowie, 35, 2/1, 455-462.

Giang N.V., Thanh L.N., Dung N.Q., \& Guy M., 2012. The assessment of sub-surface contaminant spread around the Dong Thanh waste deposit Ho Chi Minh City by near-surface geophysical data. Journal of Earth Sciences, 3 (34) [in Vietnamese].

Giang N.V., Duan N.B., Thanh L.N. \& Noboru H., 2013. Geophysical techniques to aquifer locating and monitoring for industrial zones in north Hanoi, Vietnam. Acta Geophysica, 61, 6, 1573-1597.

Giang N.V., Thanh L.N., Hiep V.Q. \& Noboru H., 2014. Hydrological and hydrogeological characterization of groundwater and river water in the North Hanoi industrial area, Vietnam. Environmental Earth Sciences, 71, 4915-4924.

Gołębiowski T., Żogała B., Mendecki M. \& Małysa T., 2017. The application of electromagnetic methods for polymetallic prospecting in mining conditions. Geology, Geophysics and Environment, 43, 3, 181-189.

Gourry J.C., Vermeersch F., Garcin M. \& Giot D., 2003. Contribution of geophysics to the study of alluvial deposits: a case study in the Val d'Avaray area of the River Loire, France. Journal of Applied Geophysics, 54, 35-49.

Linh D.V. et al., 2015. Project "Investigation, assessment of neo-geodynamics to improve the climate change scenario and proposing the adaptive measures in Mekong Delta”. South Vietnam Geological Mapping Division [in Vietnamese].

Loke M.H., Chambers J.E., Rucker D.F., Kuras O. \& Wilkinson P.B., 2013. Recent developments in the direct-current geoelectrical imaging method. Journal of Applied Geophysics, 95, 135-156.

Malleret L., 1959. L’Archéologie du Delta du Mékong, Tome Premier, L'Exploration Archéologiqueet les fouilles d'OcÈo. École Française d'Extrême-Orient, Paris. 
Malleret L., 1963. L’Archéologie du Delta du Mékong, Tome Quatrième, Le Cisbassac. École Française d'Extrême-Orient, Paris.

McNeil J.D., 1985. Technical Note TN-6, Electromagnetic terrain conductivity measurement at low induction numbers. Geonics, Mississauga, Ontario, Canada.

Neary M.P., 1999. ${ }^{14}$ C Age dating by Benzene Synthesis \& Liquid Scintillation Counting. University of Georgia, USA.

Osinowo O. \& Falufosi M.O., 2018. Application of radial electrical resistivity profile array for mapping deep vertical fractures in a proposed engineering construction site within the University of Ibadan Campus, Southwestern Nigeria. Geology, Geophysics and Environment, 44, 3, 329-338.

Paris P., 1931. Anciens canaux reconnus sur photographies aériennes dans les provinces de Ta Kèv et de Châu Đốc. Bulletin de L'École françaised'Extrême-Orient, 31, 1, 221-224.

Paris P., 1941. I. Anciens canaux reconnus sur photographies aériennes dans les provinces de Takeo, Châu Đốc, Long Xuyên et Rạch Giá (Complémentà la note parue dans Bulletin de l'École française d'Extrême-Orient, 1931, p. 221 et suivantes). Bulletin de l'École françaised'Extrême-Orient, 41, 365-370.
Paris P., 1941. II. Autres canaux reconnus à l'Est du Mékong par examen d'autres photographies aériennes (provinces de Châu Đốc et de Long Xuyên). Bulletin de l'École françaised'Extrême-Orient, 41, 371-372.

Selim E.I., Basheer A.A., Elqady G. \& Hafez M.A., 2014. Shallow seismic refraction, two-dimensional electrical resistivity imaging, and ground penetrating radar for imaging the ancient monuments at the western shore of Old Luxor city, Egypt. Archaeological Discovery, 2, 31-43.

Telford W.M., Geldart L.P. \& Sheriff R.E., 1990. Applied Geophysics. $2^{\text {nd }}$ ed. Cambridge University Press, Cambridge.

Thanh L.N., Thuan N.V., Trung D.H. \& Triet V.M., 2013. Combination of ground penetrating radar and electrical prospecting for exploring shallow geological structure. Journal of Marine Sciences and Technology, 3A (13) [in Vietnamese].

Thuyen L.X., 2005. Eco-geological analysis to identify ancient canal bed of Oc Eo culture. Journal of Archaeology, 4, 136 [in Vietnamese].

Vogelsang D., 1995. Environmental Geophysics: a Practical Guide. Springer-Verlag Berlin Heidelberg.

Xue Z., Liu J., DeMaster D., Lap V.N. \& Ta K.O., 2010. Late Holocene Evolution of the Mekong Subaqueous Delta, Southern Vietnam. Marine Geology, 269, 46-60. 